\title{
Evaluating the Impact of Providing Training for Direct Care Staff in how to Provide an Emotionally Nurturing Environment for People with Intellectual Disability and Complex Needs
}

\author{
Pat Frankish
}

\author{
Pat Frankish Psychology and Psychotherapy Consultancy, UK
}

\begin{abstract}
The service is providing supported living for a number of people, male and female, age 21 to 55 , who all have intellectual disability and a range of extra needs. These include physical disability, communication difficulties, trauma related personality difficulties, self-harming behaviour and aggression towards others. They are all perceived to have emotional developmental needs, all having suffered traumatic experiences in early childhood, causing developmental delay. All have difficulties with relationships associated with attachment disorders.

All direct support staff are trained in models of emotional development and how to assess the emotional level, which leads to identifying the needs. Managers of services are alto trained to support the staff to provide the level of support needed, and to understand the systemic effects of trauma so as to be able to provide trauma-informed-care.

The training, supervision, support and individual therapy for clients, where needed, is provided by psychologists and psychotherapists trained in Disability Psychotherapy. The comprehensive approach allows people with very complex and distressed behaviour to live in ordinary housing in the community.

Data is provided on 10 people, the history, the initial problem behaviour and the present position after being provided with the emotionally nurturing environment.
\end{abstract}

Keywords: Intellectual Disability, Staff Training, Attachment disorders, Psychotherapy, Complex Behaviour.

\section{INTRODUCTION}

People with intellectual disability (ID) and complex emotional problems often find themselves being treated in conditions of security because of fears of violence, self-harm or both. Physical restraint and seclusion are sometimes the response to extremes of behaviour and this has led to questions about the suitability of such placements. This paper provides a community alternative model for the complex people in the ID population, where traditional models had previously failed to have an impact. The emphasis is on providing staff training in the provision of an emotionally nurturing environment. Training is provided at levels 1 and 2 for direct support staff, level 5 for managers of services, and level 7 (masters level) for those providing therapy and emotional support for other staff. There were no adjustments to staffing levels, only to their level of competence to provide the model of support.

The individuals being supported all presented with complex behaviour, often described as challenging. Each of their stories warrants a paper in itself so there will only be brief summaries provided here.

The model is based on the theoretical position of Margaret Mahler [1] and has been developed by

*Address correspondence to this author at the Artemis House, 25 High Street, Kirton Lindsey, Gainsborough, DN21 4LX, UK; Tel: 01652 648335; Fax: 01652 648235; E-mail: pat.frankish@patfrankish.co.uk
Frankish [2, 3] for use with people with intellectual disabilities.

\section{METHOD AND DESCRIPTION OF TRAINING}

The training has been developed over several years to include the work of Winnicott [4], Bowlby [5], Mahler [1], Klein [6], Bion [7] and Sinason [8] in particular, and all staff are introduced to some theory that gives them an understanding of attachment, the consequences of attachment difficulties and the vulnerability to attachment problems for children with ID. The adults with ID are found to have emotional developmental stages of young children, although physically and cognitively they are much further forward. The desynchrony is a big factor and staff are taught how to recognise this, then develop ways of working that accommodates the need, as well as enabling progress to more emotional maturity.

The level 1 course is one day face to face or can be accessed on-line. It is a basic introduction to the ideas. Level 2 is provided on-line and contains stop and think questions, as well as written assignments. There is approximately 30 hours of direct study with an expectation that individuals will complete some selfdirected study of the books and observations of the people they support.

The level 5 course goes into more depth with the material from level 2, and adds systems theory, 
together with an understanding of the particular elements of systems for different types of disability. It covers all disabilities, not just ID, and provides senior staff with the knowledge they need to manage a support group who are skilled at level 2. There are 3 modules, each taking $30 \mathrm{hrs}$ of mixed taught and independent learning.

The level 7 course in Disability Psychotherapy is a 4 year part-time course, covering the content of level 5, a year at level 6 , and then a piece of research at level 7. Included in the course is supervision for clinical practice. Students receive an Advanced Diploma on completion. They are then able to provide individual therapy for people with disabilities and supervision and support for level 2 and 5 staff.

A whole staff team have been trained and provide supported living services for 17 people with complex needs. Not all of them have ID so ten people are reported on here. All of these ten people have long histories in services and prior to this approach being offered, were stuck in maladaptive patterns of behaviour.

\section{RESULTS}

Below is a Table 1 with brief details of the ten people studied. The time frame varies between 3 and 10 years. Age and length of time in "care" have not been found to be variables affecting outcome. All participants have been supported by staff who are trained to provide a nurturing environment and all have progressed in terms of their maturity and reduction in problem behaviour. All are now living in ordinary houses in ordinary locations, with staff support. The number of staff and contact hours vary, with some receiving 1:1 support with others having shared support. Prior to being given this opportunity they were all considered to be serious problems to their service providers, with lots of hospital attendances, medication and failed placements. Each one could have a whole paper written about them, so this is a summary to indicate the impact of the staff training. It is important to remember that, prior to this type of intervention, there was no change in their persistent behaviours for many years.

\section{DISCUSSION}

Clearly these brief results can only give a flavour of what is achieved, but sufficient to give credence to the impact of staff training in the developmental model. All of the individuals had been stuck for many years in their patterns of behaviour. All exhibited distress and most were medicated. The details are not included as it is the staff training that is being considered. Having a trained staff group improves staff retention resulting in very low staff turnover. Job satisfaction increases when they know what they are doing and why they are doing it.

Table 1:

\begin{tabular}{|c|c|c|c|}
\hline & History & Problem Behaviours & Present position \\
\hline 1 & Institutional care for many years & $\begin{array}{l}\text { Extreme self-harm and attacks on } \\
\text { others. } 3: 1 \text { staff ratio }\end{array}$ & No self-harm or attacks, $1: 1$ staff ratio \\
\hline 2 & $\begin{array}{l}\text { Child sexual abuse and } \\
\text { abandonment }\end{array}$ & Self-harm and isolation & No self-harm. Joins in activities with others \\
\hline 3 & CSA, foster care, abandonment & $\begin{array}{c}\text { Demanding, making false allegations, } \\
\text { unsettled }\end{array}$ & Settled for five years and sharing \\
\hline 5 & Residential care, family violence & Attacks on others with weapons & $\begin{array}{c}\text { Shares a house, attacks occasionally, no } \\
\text { weapons }\end{array}$ \\
\hline 6 & Physical abuse and neglect & $\begin{array}{c}\text { Destructive of property, inappropriate } \\
\text { urination }\end{array}$ & $\begin{array}{c}\text { Reduction in both behaviours, increase in socia } \\
\text { engagement }\end{array}$ \\
\hline 10 & $\begin{array}{l}\text { Extreme physical disability and } \\
\text { need for full care }\end{array}$ & Obstructive to carers, outbursts of anger & $\begin{array}{c}\text { Less incidents, more acceptance of what can't } \\
\text { be changed }\end{array}$ \\
\hline
\end{tabular}


The commitment to the training has been encouraging, with some staff undertaking this sort of learning for the first time in their lives. Some have done basic qualifications in "care" but had not previously felt enabled to work with the more complex people. Improved competence leads to improved confidence, which in turn reduces anxiety and fear. As fear is the largest element with adults who are emotionally small children, it helps when the staff are confident and understanding. As everyone is less fearful and more confident the atmosphere is more relaxed. This reduces the likelihood of incidents caused by environmental pressures.

\section{CONCLUSIONS}

Providing staff training around a model of emotional development enables all staff at all levels to be more competent and confident. This in turn provides a nurturing environment in which people with very complex needs, intellectual disability and traumatic histories, can thrive and enjoy a better quality of life.

The training can be accessed in as economical a way as possible, making good use of the on-line platform with face-to face sessions when required [9]. Face to face can be useful to start off a new staff group as this enables them to develop together. The level 1 can be provided in a one day session if requested and then level 2 can be completed on-line. Staff at all levels of education have been able to benefit from the training.

\section{REFERENCES}

[1] Mahler M, Pine F, Bergman A. The Psychological Birth of the Human Infant. New York: Basic Books 1979.

[2] Frankish P, Measuring the Emotional development of adults with ID. Advances in mental Health and Intellectual Disabilities 2013; 7(5): 272-276.

[3] Frankish P, Disability Psychotherapy - an Innovative Approach to Trauma-Informed Care. Karnac. London 2016.

[4] Winnicott DW, Winnicott C. Home is Where we Start From. Penguin 1990.

[5] Bowlby J. A Secure Base - The Making and Breaking of Affectional Bonds. Routledge Classics (1979 reprinted 2005).

[6] Klein M, Envy and Gratitude. Reprinted 1997 Vintage 1946.

[7] Bion W. Attacks on linking. International Journal of Psychoanalysis 1959; 40.

[8] Sinason V. Mental handicap and the human condition; New Approaches from the Tavistock. London: Free Association Books 1992.

[9] www.frankishtraining.co.uk

Received on 11-11-2015

Accepted on 07-12-2015

Published on 14-03-2016

\section{DOI: http://dx.doi.org/10.6000/2292-2598.2016.04.01.5}

(c) 2016 Pat Frankish; Licensee Lifescience Global.

This is an open access article licensed under the terms of the Creative Commons Attribution Non-Commercial License (http://creativecommons.org/licenses/by-nc/3.0/) which permits unrestricted, non-commercial use, distribution and reproduction in any medium, provided the work is properly cited. 